\title{
THE EFFECTIVENESS OF TEACHERS' INDIRECT FEEDBACK FOR STUDENTS' WRITING PERFORMANCE ON DESCRIPTIVE TEXT
}

\author{
Aisyah Kamilia; Bita Dwi Rahmani; Siswana \\ University of Muhammadiyah Prof. Dr. HAMKA \\ Aeesy2442@hotmail.com; bitadwi@gmail.com; Siswana@gmail.com
}

\begin{abstract}
This quasi-experimental study aimed to discover the empirical evidence on the effectiveness of employing teachers' indirect feedback on students' writing skills of the descriptive text in one senior high school in Indonesia. The participants of the research are 52 students in total comprising 26 students from science program class assigned as experimental group, and 26 students from social program class as control group. This research implemented teachers' indirect feedback in the experimental group for 6 meetings with the descriptive text topic based on the 2013 curriculum. On data collection, the descriptive writing test was employed, then, the data was analyzed by using SPSS version 25 software program. Based on the analysis of the data, it is yielded that there is a significant increase in the mean of post-test scores of the science class which is from 62.84 to 79.97. In addition, the post-test means score in the social class growth as well from 58.96 to 63.00 . It is assumed that the implementation of teachers' indirect feedback is effective to improve students' skill in writing descriptive text.
\end{abstract}

Keywords: Teachers' Feedback, Indirect Feedback, Writing Descriptive Text

\section{INTRODUCTION}

In the term of skills, writing is presumably the difficult one to achieve due to the requirement to make it fluent, coherent and extended (Richards \& Rendaya, 2002) . Furthermore, for the non-native speakers, writing becomes harder to master because of its complexity. Besides the considerable knowledge and cognitive effort, the particular skill ranges from the simpler ones such as spelling, pronunciation, vocabulary and word choice to the higher-level skills, such as planning and organizing text (Almasi \& Tabrizi, 2016). With the complexity of writing, it is understandable for English Foreign Learners (EFL), especially those who are still in senior high schools in Indonesia have a difficult time in their writing practices (Jati, 2018).

In Indonesia, as the 2013 Curriculum in 2018 revision stated one of the skills that students should achieve is writing a descriptive text. It is a text which is composed to explain a particular thing, person, or place by specifying its characters, components or qualities (Benyamin, 2019, p. 79). Additionally, in writing this text, the students are expected to write it accurately for explaining specific things in three or four paragraphs with the right language features and correct grammatical forms.

In practice, even though a descriptive text is categorized as a simple text, some EFL students still find obstacles in arranging words into sentences to produce good essay composition. According to Lee (2008) the problem that occurs in the writing classroom is that the students have low grammar proficiency and organization skill in relation to the text.

From the statement above by Lee, the low grammar proficiency and organization skill in relation to the text happen in some Indonesian schools such as SMA Muhammadiyah 1 Depok. According to the writers' observation at this school, the writer discovered the tenth grade students found it difficult in composing descriptive text. The students' lacked knowledge of how to determine main and detailed ideas. Hence, the students chose to compose simple text. Besides that, they got confused about what they wanted to write on 
their papers. Even though the students had some ideas, they still found some difficulties to arrange their ideas on their first writing draft. Hence, the students had obstacles in putting their words into the appropriate order, thus producing incorrect sentences. In addition, the low grammatical proficiency of the students consequently had negatives effects on their writing performance.

Furthermore, the grammatical proficiency of writing is one of the most important considerations for assessing students' writing skills. Accordingly, the main concern of many foreign language teachers is to assist the EFL learners in producing accurate writing. Nassaji \& Kartcahava $(2017$, p.1) stated that one of the reputable techniques that can be employed by the teachers is teachers' feedback. Teacher feedback refers to utterances that indicate to the students that their output is erroneous in some ways. Furthermore, there are two types of teachers' feedback, direct and indirect. Direct feedback (DF) provides the correct form explicitly from the students' mistakes (Elwood \& Bode, 2014; Jamalinesari, Rahimi, Gowhary, \& Azizifar, 2015; Jati, 2018). Meanwhile, indirect feedback (IF) is provided by the teacher though giving notes to the pupils on their error by giving the symbols or codes on the students' writing drafts (Tang \& Liu, 2018).

In teaching writing that employs teachers' feedback, the teachers provide notes about the errors in writing drafts that are composed by the students. Most of the L2 teachers in Indonesia have been employing teachers' direct feedback. This type of feedback is also employed in SMA 1 Jogonalan, Cental Java, as it is the easiest form to make the students understand and revise their errors. However, direct feedback is not the most valuable option for the long term learning process (Diab, 2015). On the other hand, indirect feedback is the valuable choice in improving students' writing performance (Bitchener \& Knoch, 2010).

Additionally, there were several studies about teachers' indirect feedback as an effective method in improving students' performance in their writing skills. One of the studies is by Jamalinesari et al., (2015). They conducted a study on investigating the effectiveness of two different types of feedback on students' writing performance regarding eight grammatical errors. The study reported that the students who received indirect corrective feedback performed better than those who received direct feedback on their accuracy on the new writing task. According to the advantages of teacher feedback from the previous study mentioned above, and relating the facts with the students' difficulties on composing simple essays of descriptive text, the writer assumes that teachers' indirect feedback may be a proper technique for assisting the tenth-grade students in SMA Muhammadiyah 1 Depok to increase their skill in writing descriptive texts.

The writer limits the scope of the research on the treatment form in teachers' feedback which is indirect type of feedback. The student as the sample of the research is limited to the $\mathrm{X}$ classes. The genre of the text is confined to descriptive text. Furthermore, the study is intended to examine whether the teachers' indirect feedback is effective for the students' writing performance of descriptive text at the tenth grade in the first semester of SMA Muhammadiyah 1 Depok in the 2019/2020 academic year. Thus, the hypotheses were:

$\mathrm{H}_{0} \quad: \mu_{1}=\mu_{2} \quad$ (Teachers' Indirect Feedback is not effective in improving tenth grade students' ability in writing descriptive text of the first semester in SMA Muhammadiyah 1 Depok in 2019/2020 academic year.)

$\mathrm{H}_{1} \quad: \mu_{1}>\mu_{2} \quad$ (Teachers' Indirect Feedback is effective in improving tenth grade students' ability in writing descriptive text of the first semester in SMA Muhammadiyah 1 Depok in 2019/2020 academic year.) 


\section{METHOD}

The study was conducted in Muhammadiyah 1 Senior High School Depok, Indonesia. There were 52 students participated in this study. The students were equally assigned to control and experimental class (26 students each). In this study, the writer employed a quantitative method which was aimed to observe the EFL learners' performance in writing descriptive text after the implementation of the teachers' indirect feedback in the learning and teaching process. Teachers' indirect feedback (IF) was implemented in the experimental class for 6 times meeting. IF is provided by the teacher through giving notes to the pupils on their error by giving the symbols or codes on the pupils' writing drafts(Tang \& Liu, 2018).

The process of implementing IF is as follows: The teacher as a facilitator introduces the topic of composition, and the students are asked to make a draft - it can be free writing or guided writing. Next, the teacher employs teachers' indirect feedback, underlining or giving codes on students' error. The students receive corrections and are demanded to make the selfcorrection based on their knowledge. The students' return their drafts to the teacher. The teacher corrects the students' revision.

For collecting the data, the students were asked to do pre-test and post-test of writing descriptive text about tourism place in Indonesia, with the minimum of words is 150 . Then, normality and homogeneity test were calculated employing SPSS version 25 software program, and for the t-test was manually calculated.

\section{FINDINGS}

The t-test is a crucial calculation of this study to find out the research problem about whether teachers' indirect feedback affects students' writing descriptive text. Before the writer calculated the results using the t-test, the writer compared the gained score from both experiment (x) and control (y) classes in the following table:

Table 1.1 : Comparison between the scores of two classes

\begin{tabular}{|c|c|c|c|c|c|c|}
\hline No & $\mathbf{X}$ & $\mathbf{Y}$ & $\mathbf{X}=\mathbf{X}-\mathbf{M}_{\mathbf{X}}$ & $\mathbf{Y}=\mathbf{Y}-\mathbf{M}_{\mathbf{Y}}$ & $\mathbf{X}^{\mathbf{2}}$ & $\mathbf{y}^{\mathbf{2}}$ \\
\hline 1 & 8 & 0 & -6.9 & -4.03 & 49.61 & 16.24 \\
\hline 2 & 8 & 4 & -6.9 & -0.03 & 49.61 & 0.09 \\
\hline 3 & 5 & 7 & -9.9 & -13.93 & 98.01 & 194.04 \\
\hline 4 & 20 & 8 & 5.1 & 3.97 & 26.01 & 15.76 \\
\hline 5 & 12 & 2 & -2.9 & -2.03 & 8.41 & 4.12 \\
\hline 6 & 3 & -3 & -11.9 & -7.03 & 141.61 & 49.42 \\
\hline 7 & 27 & 1 & 12.1 & -3.03 & 146.41 & 9.18 \\
\hline 8 & 25 & 15 & 10.1 & 10.97 & 102.01 & 120.34 \\
\hline 9 & 20 & 9 & 5.1 & 4.97 & 26.01 & 24.70 \\
\hline 10 & 14 & 1 & -0.9 & -3.03 & 0.81 & 9.18 \\
\hline 11 & 14 & 4 & -0.9 & -0.03 & 0.81 & 0.09 \\
\hline 12 & 10 & 1 & -4.9 & -3.03 & 24.01 & 9.18 \\
\hline 13 & 23 & 17 & 8.1 & 12.97 & 65.61 & 168.22 \\
\hline 14 & 23 & -1 & 8.1 & -5.03 & 65.61 & 25.03 \\
\hline 15 & 26 & 5 & 12 & 0.97 & 144 & 0.94 \\
\hline 16 & 25 & 14 & 10.1 & 9.97 & 102.01 & 99.40 \\
\hline 17 & 5 & -18 & -9.9 & -22.03 & 98.01 & 485.32 \\
\hline
\end{tabular}




\begin{tabular}{|c|c|c|c|c|c|c|}
\hline 18 & -7 & 12 & -21.9 & 7.97 & 479.61 & 63.52 \\
\hline 19 & 19 & -12 & 4.1 & -16.03 & 16.81 & 256.96 \\
\hline 20 & 20 & 2 & 5.1 & -2.03 & 26.01 & 4.12 \\
\hline 21 & 18 & 10 & 3.1 & 5.97 & 9.61 & 35.64 \\
\hline 22 & 26 & 0 & 11.1 & -4.03 & 123.21 & 16.24 \\
\hline 23 & 3 & 2 & -11.9 & -2.03 & 141.61 & 4.12 \\
\hline 24 & 16 & 4 & 1.1 & -0.03 & 1.21 & 0.0009 \\
\hline 25 & 13 & 15 & -1.9 & 10.97 & 3.61 & 120.34 \\
\hline 26 & 12 & 6 & -2.9 & 1.7 & 8.41 & 2.89 \\
\hline$\sum=\mathbf{2 6}$ & $\mathbf{3 8 8}$ & $\mathbf{1 0 5}$ & & & 1958.65 & $\mathbf{1 7 3 5 . 0 8}$ \\
\hline
\end{tabular}

The writer involved the sample of post-test score of tenth grade students using manual calculation of t-test formula as follows:

a. Determining Mean Variable $X$ :

$$
M x=\frac{\Sigma x}{n x}=\frac{388}{26}=14.9
$$

b. Determining Mean Variable Y:

$$
M y=\frac{\Sigma y}{n y}=\frac{105}{26}=4.03
$$

c. Determining Deviation Standard of Score of Variable X:

$$
S D x=\sqrt{\frac{\sum x^{2}}{n x}}=\sqrt{\frac{1958.65}{26}}=\sqrt{75.33}=8.7
$$

d. Determining Deviation Standard of Score of Variable Y:

$$
S D y=\sqrt{\frac{\Sigma y^{2}}{n y}}=\sqrt{\frac{1735.08}{26}}=\sqrt{67.42}=8.2
$$

e. Determining Standard Error of Mean Variable X:

$$
\operatorname{SEmx}=\frac{S D x}{\sqrt{n x-1}}=\frac{8.7}{\sqrt{25}}=1.74
$$

f. Determining Standard Error of Mean Variable Y:

$$
\text { SEmy }=\frac{S D y}{\sqrt{n y-1}}=\frac{8.2}{\sqrt{25}}=1.64
$$

g. Determining Standard Error of difference of Mean Variable X and Mean Variable Y:

$$
\begin{aligned}
S E_{M x-M y} & =\sqrt{S E M x^{2}+} S E M y^{2} \\
& =\sqrt{1.74^{2}+} 1.64^{2}=\sqrt{3.02+2.68} \\
= & \sqrt{5.7} \\
= & 2.38
\end{aligned}
$$

h. Determining $t_{o}$ with formula:

$$
t_{o}=\frac{M x-M y}{S E M x-M y}=\frac{14.9-4.03}{2.38}=\frac{10.87}{2.38}=4.56
$$

i. Determining degree of freedom:

$$
\mathrm{df}=(\mathrm{nx}+\mathrm{ny})-2=(26+26)-2=50
$$


Through the t-test calculation above, it could be seen that degree of freedom (df) of $\mathrm{N}$ is 50. T-test yields the score 4.56. The preceding procedures were functioned to test Alternative Hypothesis $\left(\mathrm{H}_{\mathrm{i}}\right)$ which was accepted or not. On the 0.05 level of significance with the degree of freedom 25 , the critical value of $t_{t}$ is 1.71 . From the calculation above, the outcome of $t_{0}$ is 4.56. It appeared the $t_{o}$ was higher than the $t_{t}$. Therefore, the Null Hypothesis is rejected.

\section{DISCUSSION}

According to the result of the data description above, the writer concluded that there were significant differences in the mean of the post-test score between control and experiment class. The mean of the post-test in the experiment class (79.92) was higher than the control class (63.00). Moreover, there was a significant improvement in the post-test score after the writer implemented teachers' indirect feedback during 6 meetings in the teaching and learning process. The mean post-test score in the experiment class was 65.35 and increased to 79.92.

Meanwhile, based on data analysis, the t-test result showed that $t_{0}=4.56$, and it is higher than $t_{t}$ with the significance level $0,05=1.71$. Hence, $H_{i}$ is accepted because $t_{0}$ higher than $t_{t}$ or it could be described as $4.56>1.71$ and $\mathrm{H}_{0}$ is rejected.

Furthermore, teaching in tenth-grade aims to make the students write descriptive text well organized with correct grammatically. The data showed that the students could write descriptive text better structurally and grammatically because of the implementation of indirect feedback in the class. Furthermore, the tenth-grade students' awareness in producing a good text increased. This is in the same line as Ellis \& Loewen (2009) statement that implementing Indirect Feedback in writing classrooms is believed to build students' awareness of error and challenges the students to perform self-correction. In addition, in the same line as Hylands' statement that feedback is an input for the writers to develop their work through a letter of revision. These encourage the students to think about checking their writing tasks and do the revision before the final result. As the revision is one of the important stages of writing that is stated by Harmer (2004).

In brief, teachers' indirect feedback can provide a beneficial impact on enhancing pupils' ability in writing a descriptive text by the improvement of the students' performance. Furthermore, it improves the student in choosing the word and put the right word order on their writing.

Thus, the result answers the question of whether teachers' indirect feedback is effective in teaching writing skills of descriptive text. In other words, there is a significant effect in teaching descriptive text employs indirect feedback at the tenth-grade in the first semester of SMA Muhammadiyah 1 Depok in 2019/2020 Academic Year.

\section{CONCLUSION}

This study has revealed useful finding on the use of teachers' Indirect Feedback (IF) in Indonesian senior high school context. Within six-meeting treatment in the experiment class, indirect feedback could improve students' writing performance especially on descriptive text. It could be seen from the measurement of the improvement after post-test. 
However, within a short period of time, IF wouldn't give significant improvement for the students. In addition, IF would be really effective for the long-term process. In addition, the use of IF requires more time for its effect to be appreciated (Ellis \& Loewen, 2009). Furthermore, this study was conducted at the senior high school level. Therefore, further researchers can attempt to discover the effect of using indirect feedback on different levels of education.

\section{REFERENCES}

Almasi, E., \& Tabrizi, A. R. N. (2016). The effects of direct vs. indirect corrective feedback on iranian efl learners' writing accuracy. Journal of Applied Linguistics and Language Research, 3(1), 74-85.

Benyamin, H. (2019). Bahasa inggris. (Y. Farlina \& A. Septiany, Eds.). Bandung: Grafindo Media Pratama.

Bitchener, J., \& Knoch, U. (2010). Raising the linguistic accuracy level of advanced L2 writers with written corrective feedback. Journal of Second Language Writing, 19, 207217. https://doi.org/doi:10.1016/j.jslw.2010.10.002

Diab, N. M. (2015). Effectiveness of written corrective feedback: does type of error and type of correction matter? Assessing Writing, 24, 16-34. Retrieved from http://dx.doi.org/10.1016/j.asw.2015.02.001

Ellis, R., \& Loewen, S. (2009). Implicit and explicit corrective feedback and the acquisition of 12 grammar. Cambridge: Cambridge University Press. https://doi.org/DOI: 10+10170S0272263106060141

Elwood, J. A., \& Bode, J. (2014). Student preferences vis-à-vis teacher feedback in university efl writing classes in japan. System, 42, 333-343.

Harmer, J. (2004). How to teach writing. Essex: Pearson Education, Inc.

Jamalinesari, A., Rahimi, F., Gowhary, H., \& Azizifar, A. (2015). The effects of teacherwritten direct vs. indirect feedback on students' writing. Social and Behavioral Sciences, 116 - 123. https://doi.org/doi: 10.1016/j.sbspro.2015.06.018

Jati, S. O. (2018). The effect of teacher's indirect feedback on descriptive writing at sma alazhar 3 bandar lampung.

Nassaji, H., \& Kartcahava, E. (2017). Corrective feedback in second language teaching and learning. Routledge.

Richards, J. C., \& Rendaya, W. A. (2002). Methodology in language teaching: an anthology of current practice. Cambridge University Press. https://doi.org/https://doi.org/10.1017/CBO9780511667190 
Tang, C., \& Liu, Y.-T. (2018). Effects of indirect coded corrective feedback with and without short affective teacher comments on 12 writing performance, learner uptake and motivation. Assessing Writing, 35, 26-40. Retrieved from https://doi.org/10.1016/j.asw.2017.12.002 